\title{
The influence of corporate culture and organisational commitment on performance
}

\begin{abstract}
This paper examines the influence of corporate culture and organisational commitment on financial performance in Malaysian companies. Based on the work of Deshpande and Farley on corporate cultural types and Allen and Meyer on organisational commitment, a structured questionnaire was developed and self-administered to managers in Malaysian companies. A total of 202 managers in public listed companies participated in the study. The results show that there is a significant correlation between corporate culture and organisational commitment. Both corporate culture type and organisational commitment have an influence on the financial performance of these companies. The implications of the study are also discussed.
\end{abstract}

Keyword: Organisational culture; Performance levels; Malaysia 